\title{
Gambaran Kejadian Medication Error pada Resep Anak di Apotek
}

\author{
Profile of Medication Error in Children's Prescriptions at the Pharmacy \\ Dian Oktianti $^{(1)}$, Thalia Dwi Septiyawati ${ }^{(1)}$,Nurul Huda Setiawan ${ }^{(1)}$ \\ (1)Prodi Farmasi, Universitas Ngudi Waluyo, Ungaran \\ Email : di4n.oktianti@gmail.com
}

\begin{abstract}
ABSTRAK
Resep merupakan alat komunikasi yang digunakan oleh dokter, apoteker dan pasien dalam suatu proses terapi. Kelengkapan resep merupakan hal penting dalam peresepan karena bisa mengurangi adanya medication error. Medication error pada anak memiliki resiko lebih besar dibanding pasien dewasa karena anak membutuhkan perhitungan dosis berdasarkan usia, berat badan, luas daerah permukaan tubuh dan kondisi penyakitnya. Hal ini disebabkan karena pada pasien anak parameter farmakokinetiknya belum berkembang secara optimal. Penelitian ini bertujuan untuk menganalisis pada aspek administratif resep anak usia 0-7 tahun di Apotek X Semarang dan Apotek Y di Ungaran bulan Januari-Mei 2021. Penelitian ini menggunakan rancangan penelitian deskriptif yang bersifat retrospektif, dengan melakukan analisis data terhadap kelengkapan resep diaspek administratif. Penetapan sampel pada penelitian ini menggnakan pengambilan sampel secara total sampling dengan mempertimbangkan kriteria yang telah ditentukan, yaitu resep anak usia 0-7 tahun dan dapat terbaca. Jumlah sampel resep yang digunakan adalah sebanyak 125 lembar resep. Berdaarkan hasil penelitian yang dilakukan pada aspek kelengkapan resep bulan Januari-April 2021 didapatkan hasil sebagai berikut: Nama dokter 94,32\%, Nomor surat izin praktik (SIP) 38,41 \%, Alamat praktik dokter 100\%, Nomor telepon 97,73\%, Tanggal penulisan resep 93,18\%, Paraf dokter 51,85\%, Nama pasien $100 \%$, Jenis kelamin pasien 9,9\%, Umur pasien $100 \%$, Berat badan pasien 16,01\%. Kelengkapan administratif yang sudah memenuhi persyaratan adalah alamat praktek dokter, nama pasien, umur pasien.
\end{abstract}

\section{Kata kunci : Kelengkapan, Resep, Ana, Administratif}

\begin{abstract}
Prescription is a communication tool used by doctors, pharmacists and patients in a therapeutic process. Completeness of prescription is important in prescribing because it can reduce medication errors. Medication errors in children have a greater risk than adult patients because children need dose calculations based on age, weight, body surface area and disease conditions. This is because in pediatric patients the pharmacokinetic parameters have not developed optimally. This study aims to analyze the administrative aspects of prescriptions for children aged 0-7 years at Apotek X Semarang and Apotek Y in Ungaran in January-May 2021. This study used a retrospective descriptive research design, by analyzing data on the completeness of prescriptions in the administrative aspect. Determination of the sample in this study using total sampling taking into account the predetermined criteria, namely prescriptions for children aged 0-7 years and can be read. The number of recipe samples used were 125 recipe sheets. Based on the results of research conducted on the aspect of completeness of prescriptions in January-April 2021, the following results were obtained: Doctor's name 94.32\%, Practice license number (SIP) $38.41 \%$, Doctor's practice address $100 \%$, Telephone number $97.73 \%$, Date of writing prescription
\end{abstract}




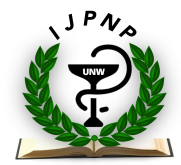

93.18\%, Doctor's initials 51.85\%, Patient's name 100\%, Patient's gender 9.9\%, Patient's age $100 \%$, Patient's weight $16.01 \%$. Administrative documents that have met the requirements are the doctor's practice address, the patient's name, and the patient's age.

Keywords: Equipment, Recipes, Children, Administrative

\section{PENDAHULUAN}

Peresepan yang tidak lengkap bisa mejadi penyebab medication error pada pasien, kejadian ini bisa dicegah dengan skrining resep oleh apoteker yang salah satunya kajian aspek administratif. Angka kejadian kesalahan peresepan yang terjadi pada pasien anak-anak terutama pada kesalahan pengobatan dapat memperburuk penyakit dan dapat mempengaruhi organ tubuhnya karna mengingat sistem enzim dalam metabolisme obat pada anak-anak belum terbentuk secara optimal (Maiz, Nurmainah \& Untari, 2014).

Medication error menjadi salah satu permasalahan yang banyak memunculkan dampak bagi pasien mulai dari resiko ringan sampai paling parah yang sebenarnya dapat dicegah. Medication error merupakan setiap kejadian yang dapat dihindari dan berakibat pada pelayanan obat yang membahayakan pasien selama berada dalam pengawasan tenaga kesehatan atau pasien (Oktarlina \& Wafiyatunisa, 2017).

Medication error bisa saja terjadi di setiap tahapan dari pengobatan, diantaranya pada tahap prescribing (kesalahan peresepan), dispensing (kesalahan penyiapan obat) dan administration (kesalahan administrasi/ penyerahan obat) yang apabila terjadi kesalahan di salah satu tahap bisa memunculkan kesalahan berantai di tahap-tahap berikutnya (Tajuddin, Sudirman, \& Maidi, 2012).

Medication Error pada fase prescribing memiliki resiko kesalahan paling besar yaitu $99,12 \%$, fase ini merupakan kesalahan yang banyak ditemukan apalagi pada pasien pediatri/ anak, baik pada administrasi yang tidak lengkap, penggunaan singkatan yang kurang lazim, maupun penulisan aturan pemakaian yang kurang jelas (Maiz, Nurmainah, \& Untari, 2014)
Faktor yang dapat menyebabkan medication error salah satunya adalah kesalahan komunikasi antara penulis resep (prescriber) dengan pembaca resep (dispenser). Kesalahan ini bisa diakibatkan dari ketidaklengkapan penulisan resep. ketidaklengkapan resep pada peresepan anak yakni tidak adanya berat badan dan umur pasien yang memiliki peran penting sebagai dasar perhitungan dosis. Selain itu, berdasarkan keadaan fisiologisnya beberapa organ pada anak belum cukup sempurna, contohnya ginjal pada anak berkembang belum sempurna sehingga kemampuan dalam hal eliminasi obat belum bekerja optimal (Maiz, Nurmainah, \& Untari, 2014).

pada penelitian Setiadi (2014) terhadap 54 resep menujukkan ketidaklengkapan pada nama dokter $64,8 \%$, berat badan pasien $62,9 \%$, umur $38,9 \%$.

Berdasarkan uraian diatas, penulis tertarik melakukan penelitian ini untuk menganalisis kelengkapan resep anak usia 0-7 tahun di Apotek X dan Y.

\section{METODE PENELITIAN}

\section{Alat dan Bahan}

Alat yang digunakan adalah lembar pengambilan data sedangkan bahan yang digunakan adalah resep pasien anak usia 0-7 tahun

\section{Metode Penelitian}

Penelitian ini merupakan penelitian non eksperimental dengan rancangan penelitian deskriptif yang bersifat retrospektif, dengan melakukan analisis data terhadap kelengkapan resep diaspek administratif di Apotek X dan Y Periode Januari - Mei 2021. Penetapan sampel pada penelitian ini menggunakan pengambilan 


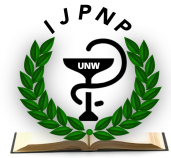

sampel secara Total Sampling dengan mempertimbangkan kriteria yang telah ditentukan. Jumlah sampel dari apotek $\mathrm{X}$ sebanyak 81 lembar dan apotek Y 44 lembar resep

Kriteria inklusi dari penelitian ini adalah resep anak usia 0-7 tahun, sedangkan kriteria ekslusinya adalah apabila resep rusak dan tidak dapat terbaca. Data kemudian akan dianalisis berdasarkan kelengkapan administratif pada resep sesuai dengan Permenkes RI No. 73 tahun 2016.

HASIL DAN PEMBAHASAN

Hasil

Tabel 1. Kelengkapan Resep di Apotek X

\begin{tabular}{|c|c|c|c|c|}
\hline \multirow{2}{*}{ Kategori } & \multicolumn{2}{|c|}{ Lengkap } & \multicolumn{2}{|c|}{ Tidak Lengkap } \\
\hline & Jml & $\begin{array}{c}\text { Persen } \\
(\%)\end{array}$ & $\mathbf{J m l}$ & $\begin{array}{c}\text { Persen } \\
(\%)\end{array}$ \\
\hline Nama dokter & 81 & 100 & 0 & 0 \\
\hline $\begin{array}{l}\text { Nomor surat } \\
\text { izin praktik } \\
\text { (SIP) }\end{array}$ & 7 & 8,64 & 74 & 91,36 \\
\hline $\begin{array}{l}\text { Alamat } \\
\text { praktik dokter }\end{array}$ & 81 & 100 & 0 & 0 \\
\hline $\begin{array}{l}\text { Nomor } \\
\text { telepon dokter }\end{array}$ & 81 & 100 & 0 & 0 \\
\hline $\begin{array}{l}\text { Tanggal } \\
\text { penulisan } \\
\text { resep }\end{array}$ & 81 & 100 & 0 & 0 \\
\hline Paraf dokter & 42 & 51,85 & 39 & 48,15 \\
\hline Nama pasien & 81 & 100 & 0 & 0 \\
\hline Umur pasien & 81 & 100 & 0 & 0 \\
\hline $\begin{array}{l}\text { Jenis kelamin } \\
\text { pasien }\end{array}$ & 0 & 0 & 81 & 100 \\
\hline $\begin{array}{l}\text { Berat badan } \\
\text { pasien }\end{array}$ & 2 & 2,47 & 79 & 97,53 \\
\hline
\end{tabular}

Indonesian Journal of Pharmacy and Natural Product http:/jurnal.unw.ac.id/index.php/ijpnp Volume 04, Nomor 02 , September 2021 $p-I S S N$ : 2656-3215 e-ISSN : 2615-6903

Tabel 2. Kelengkapan Resep di apotek Y

Lengkap Tidak Lengkap

\begin{tabular}{lcccc}
\cline { 2 - 5 } Kategori & Jml & $\begin{array}{c}\text { Persen } \\
\mathbf{( \% )}\end{array}$ & Jml & $\begin{array}{c}\text { Persen } \\
\mathbf{( \% )}\end{array}$ \\
\hline Nama dokter & 39 & 88,64 & 5 & 11,36
\end{tabular}

Nomor surat

$\begin{array}{lllll}\text { izin praktik } & 30 & 68,18 & 14 & 31,82\end{array}$

(SIP)

$\begin{array}{lcccc}\begin{array}{l}\text { Alamat praktik } \\ \text { dokter }\end{array} & 44 & 100 & 0 & 0 \\ \begin{array}{l}\text { Nomor telepon } \\ \text { dokter }\end{array} & 42 & 95,45 & 2 & 4,55 \\ \begin{array}{l}\text { Tanggal } \\ \text { penulisan resep }\end{array} & 38 & 86,36 & 6 & 13,64 \\ \begin{array}{l}\text { Paraf dokter } \\ \text { Nama pasien }\end{array} & 41 & 93,18 & 3 & 6,82 \\ \begin{array}{l}\text { Umur pasien } \\ \text { Jenis kelamin }\end{array} & 44 & 100 & 0 & 0 \\ \text { pasien } & 8 & 18,18 & 36 & 81,82 \\ \begin{array}{l}\text { Berat badan } \\ \text { pasien }\end{array} & 13 & 29,55 & 31 & 70,45 \\ \end{array}$

\section{Pembahasan}

Dari data yang diperoleh pada penelitian ini dapat diketahui bahwa yang memiliki ketidak lengkapan resep menurut Permenkes No 73 Tahun 2016 diantaranya :

1. Identitas dokter

Pada hasil penelitian ini, angka kejadian medication error berdasarkan identitas dokter terdapat komponen yang tidak lengkap di apotek 
X meliputi: nomer SIP 91,36\%, paraf dokter $48,15 \%$, sedangkan di apotek Y ketidaklengkapan resep terjadi pada nama dokter $11,36 \%$, nomer SIP dokter 31,82\%, paraf dokter $6,82 \%$ dan no telepon $4,55 \%$. Hal ini sejalan dengan penelitian yang dilakukan Suryani, Desnita, \& Pratiwi (2018) mendapatkan angka kejadian pada data dokter yaitu nama dokter $1 \%$, nomer SIP dokter $26 \%$, tanggal resep $6 \%$, paraf dokter $2 \%$ dan no.telepon $16 \%$.

Pada Apotek X terdapat 91,36\% resep yang tidak mencantumkan no. SIP dokter, hal ini disebabkan sebagian besar resep yang masuk di Apotek X Semarang berasal dari dokter praktek di Klinik apotek tersebut, selain itu dokter praktek yang berada di klinik tersebut lebih dari satu sehingga resep yang dicetak hanya mencantumkan nama, alamat dan nomor telepon klinik hal ini untuk menghembat biaya operasional percetakan resep. Oleh karena itu dokter hanya menulis nama dokter tanpa menuliskan SIP nya untuk mempersingkat waktu akibat ramainya dan antrian pasien yang ada di klinik tersebut.

Di apotek Y, terdapat 14 resep yang tidak mencantumkan nomer SIP dokter berasal dari resep rumah sakit, puskesmas maupun klinik, sedangkan 5 resep tidak mencantumkan nama dokter berasal dari 1 rumah sakit yang ada di Ungaran. Hal ini disebabkan karena lembar form pelayanan tersebut berupa form elektronik yang mencantumkan identitas instansi seperti rumah sakit, puskesmas dan klinik. Ada beberapa dokter spesialis memberikan stampel berisikan nama dan nomer SIP dokter tetapi ada juga dokter yang lupa mengisikan data tersebut karena harus menuliskan secara manual. Pada kasus ini, resep tetap diterima dan dilayani apotek karena dokter tersebut sudah memiliki ijin untuk melakukan proses pelayanan kesehatan. Penulisan resep di instansi kesehatan dengan dokter praktek pribadi memiliki sedikit perbedaan. Pada penulisan nomer SIP dokter di instansi kesehatan tidak ikut dicantumkan karena dokter tersebut berada di bawah operasional instansi tersebut. Pada PERMENKES RI No 30 tahun 2019 tentang perizinan rumah sakit merupakan izin yang diberikan kepada pejabat yang bernaung di rumah sakit kepada pengelola yang melakukan proses pelayanan kesehatan sesuai dengan standar pelayanan kesehatan di rumah sakit. Sedangkan pada dokter praktek pribadi harus mencantumkan nomer SIP dokter untuk memberikan keamanan, perlindungan dan kepastian hukum bahwa dokter yang sedang melakukan perawatan pribadi ke pasien sudah sesuai dengan peraturan yang berlaku.

Faktor yang menyebabkan dokter tidak menuliskan paraf pada penelitian ini karena pelayanan resep di salah satu klinik sudah menggunakan resep elektronik yang sudah tervalidasi, sehingga meskipun tidak ada paraf dokter, resep tersebut tetap sah. Kemudian terdapat resep dari puskesmas yang tidak menuliskan paraf dokter yang berisi salep bufacort-n, alasan resep tersebut tetap diberikan di apotek saat pasien menebus resep bulan Maret 2021 dimungkinkan karena petugas lalai dalam melakukan skrining resep, kemudian bisa dijadikan pertimbangan apoteker obat yang tertera di resep merupakan Obat Wajib Apotek (OWA) sehingga pasien bisa membeli obat tersebut tanpa resep dokter.

Adanya paraf dokter dalam resep merupakan salah satu bukti bahwa resep ini dapat dijamin keaslian dan keabsahannya, serta tidak mudah disalahgunakan oleh orang umum terutama pada resep yang mengandung narkotika dan psikotropika (Pratiwi, Izzatul, \& Pratiwi, 2018).

Alamat dan no. telepon dokter merupakan hal penting dalam resep karena memberikan petunjuk ketika petugas di apotek mendapati keraguan saat melakukan skrining resep, dapat segera berkonsultasi dengan dokter yang menuliskan resep tersebut untuk melakukan konfirmasi ulang tentang resep dengan memberikan pertimbangan / alternatif bila dibutuhkan (Megawati \& Santoso, 2017). 
2. Jenis kelamin pasien

Berdasarkan tabel 1 pada apotek X didapati ketidaklengkapan sebesar $100 \%$, dan di apotek Y $81,82 \%$ hal ini sejalan dengan penelitian yang dilakukan oleh (Rauf et al, 2020) kejadian medication error yang terjadi pada jenis kelamin ditemukan sebesar 90,90\%, membuktikan bahwa pada komponen ini memiliki potensi menimbulkan medication error di apotek.

Jenis kelamin tidak kalah penting untuk dicantumkan pada resep karena berkaitan dengan identitas pasien sehingga dapat menghindari kejadian obat tertukar antara pasien satu dengan pasien lainnya saat melakukan pelayanan resep diapotek (Rauf et al, 2020).

3. Umur dan Berat badan pasien

Pada apotek X ditemukan ketidaklengkapan resep berdasarkan berat badan sebesar 97,53\% dan di apotek $\mathrm{Y}$ terdapay $81,82 \%$. Hal ini sejalan dengan penelitian yang dilakukan oleh ke (Fatimah et al, 2020) medication error yang terjadi pada berat badan pasien ditemukan sebesar $100 \%$ sehingga membuktikan bahwa pada komponen ini memiliki potensi menimbulkan medication error di apotek.

Aspek umur dan berat badan merupakan hal penting pada resep anak, karena pada bagian ini adalah dasar untuk melakukan perhitungan dosis. Adanya umur pasien penting dituliskan dalam resep karena untuk membantu dosis obat yang tepat dan bentuk sediaan yang sesuai untuk pasien (Sheikh, Mateti, Shamaprakash \& Sanal, 2017). Tujuan adanya berat badan pasien disini untuk melihat kembali kesesuaian dosis obat yang diberikan khususnya peresepan obat untuk anak-anak (Cholisoh et al., 2019).

4. Tanggal Penulisan Resep

Pada penelitian ini menunjukkan bahwa masih ada potensi medication error pada tanggal penulisan resep. Pada apotek Y masih ada $13,64 \%$ resep yang tidak mencantumkan tanggal penulisan. Tanggal penulisan resep sangat penting karena dapat menjaga keamanan pasien saat pengambilan obat sehingga apoteker dapat menentukan resep tersebut apakah masih dapat dilayani atau disarankan untuk kembali ke dokter (Megawati \& Santoso, 2017).

\section{Nama Pasien}

Nama pasien merupakan komponen yang bisa digunakan untuk melakukan konfirmasi ulang mengenai data diri pasien (Rauf et al, 2020). Hal ini berpotensi sangat fatal jika terjadinya kesalahan pemberian obat yang seharusnya diberikan kepada pasien A ternyata diberikan kepada pasien B kareana pasien tersebut memiliki nama yang sama sehingga pemberian obat tidak sesuai penyakit atau keluhan yang sedang dialami oleh pasien (Oktarlina \& Wafiyatunisa, 2017).

Bila terjadi kesalahan pada identitas pasien baik dari nama, umur, beart badan alamat ataupun jenis kelamin, dapat berakibat fatal karena dapat mempengaruhi pelayanan pengobatan akibat dari tertukarnya obat. Sesuai dengan Permenkes No 73 Tahun 2016 resep perlu dituliskan secara lengkap dan jelas. Hal ini bertujuan untuk mencegah adanya keselahan presepsi diantara dokter dan apoteker dalam hal mengartikan resep.Ketidaklengkapan administratif dimungkinkan disebabkan karena kurangnya dokter dalam memahami kelengkapan resep Ketidakjelasan penulisan resep juga dimungkinkan karena resep bersifat rahasia, oleh karena itu dokter tidak ingin pasien mengetahui resep yang dituliskan. Sehingga dapat dikatakan bahwa kesalahan aspek adimistratif masih sering terjadi di praktek dokter sehari-hari (Junus et al., 2020).

\section{SIMPULAN}

Berdasarkan hasil dan pembahasan yang telah diuraikan diatas, maka dapat diambil kesimpulan bahwa Kelengkapan administratif yang sudah memenuhi persyaratan adalah alamat praktek dokter, nama pasien, umur pasien. 


\section{UCAPAN TERIMA KASIH}

Terimakasih kepada Thalia Dwi Septiyawati, Nurul Huda Setiawan yang sudah memmbantu selama proses penelitian ini berlangsung. Serta kepada apotek yang memberikan ijin untuk pengambilan data penelitian.

\section{DAFTAR PUSTAKA}

Anonim, 2016, Permenkes RI No. 73 Tahun 2016 tentang Standar Pelayanan Kefarmasian di Apotek, Kementrian Kesehatan RI, Jakarta.

Cholisoh., Zakky., Damayanti., \& Sari. (2019). Kualitas Penulisan Resep Untuk Pasien Pediatri Di Rumah Sakit Surakarta. University Research Colloquium, diakses dari http://repository.urecol.org/index.php/procee ding/issue/view/10

Fatimah., Rochmah., \& Pertiwi. (2020). Analisis Kejadian Medication Error Resep Pasien Rawat Jalan Di Rumah Sakit X Cilacap. Jurnal Ilmiah JOPHUS: Journal Of Pharmacy UMUS 2 (01): 36-43. Diakses dari

https://doi.org/10.46772/jophus.v2i01.272.

Junus, D., Samad, M. A., Baso, A., \& Pawellangi, W. (2020). Pengaruh Kelengkapan Administrasi Terhadap Pelayanan Resep Instalasi Farmasi RSUD Haji Provinsi Sulawesi Selatan. Jurnal Manajemen Kesehatan Yayasain RS. Dr. Soetomo diakses dari .https://jurnal.stikesyrsds.ac.id/index.php/JMK/article/view/308

Maiz, N., Nurmainah., \& Untari, E. (2014). Analisis Medication Error Fase Prescribing Pada Resep Pasien Anak Rawat Jalan Di Instalasi Farmasi RSUD Sambas Tahun 2014. Jurnal Mahasiswa Farmasi. Universitas Tanjungpura, Pontianak.

Megawati., Santoso, P. (2017). Pengkajian
Resep Secara Administratif Berdasarkan Peraturan Menteri Kesehatan RI No 35 Tahun 2014 Pada Resep Dokter Spesialis Kandungan Di Apotek Stgira Dhipa. Jurnal Ilmiah Medicamento, Fakultas Farmasi, Universitas Mahasaraswati. https://doi.org/10.36733/medicamento.v3i1.1 $\underline{042}$

Oktarlina, R. Z., \& Wafiyatunisa, Z. (2017). Kejadian Medication Error pada Fase Prescribing di Poliklinik Pasein Rawat Jalan Rumah Sakit Daerah Mayjend HM Ryacudu Kota Bumi. Skripsi. Fakultas Kedokteran Universitas Lampung, 1(3), 540-545.

Pratiwi, D., Izzatul, N. R., \& Pratiwi, D. R. (2018). Analisis Kelengkapan Administratif Resep Di Apotek Bhumi Bunda Ketejer Praya, Lombok Tengah, Skripsi. Universitas Qamarul Huda Badaruddin Bagu.

Rauf, Hurria, A. I. M. J. (2020). Kajian Skrining Resep Aspek Administratif Dan Farmasetik Di Apotek CS Farma Periode Juni-

Desember 2018. Ad-Dawaa' Journal of Pharmaceutical Sciences, 3(1), Hal 33-39. https://doi.org/10.24252/djps.v3i1.14007

Setiadi, H. K. (2014). Medication Error Fase Prescribing Dan Fase Transcribing Pada Resep Racikan Untuk Pasien Pediatrik Di Rawat Inap Di RSUP DR. Sardjito Yogyakarta Periode Februari 2014. Skripsi, Universitas Sanata Dharma.

Suryani, D., Desnita R., \& Pratiwi L. (2018). Kajian Administratif Dan Farmasetis Resep Di Salah Satu Sarana Apotek Kota Pontianak Pada Periode Januari-Desember 2018. Kedokteran. Diakses pada https://doi.org/10.1097/00152193198512000-00002.

Tajuddin., Sari, R., Sudirman, I., Maidin, A. F. (2012). Faktor Penyebab Medication Error 
Di Instalasi Rawat Darurat. Makassar:

Universitas Hasanuddin. Jurnal

Manajemen Pelayanan Kesehatan, Universitas Gadjah Mada, Yogyakarta. 